\title{
Encounters between Jesuit and Protestant Missionaries in their Approaches to Evangelization in Zambia
}

Choobe Maambo, s.J.

Africa's reception of Christianity and the pace at which the faith permeated the continent were incredibly slow. Although the north, especially Ethiopia and Egypt, is believed to have come under Christian influence as early as the first century, it was not until the fourth century that Christianity became more widespread in north Africa under the influence of the patristic fathers. From the time of the African church fathers up until the fifteenth century, there was no trace of the Christian church south of the Sahara. According to William Lane, s.J.:

It was not until the end of the fifteenth and sixteenth centuries that Christianity began to spread to the more southerly areas of Africa. The Portuguese, in their search for a sea route to India, set up bases along the East and West African coasts. Since Portugal was a Christian country, missionaries followed in the wake of the traders with the aim of spreading the Gospel and setting up the Church along the African coasts. ${ }^{1}$

Prince Henry the Navigator (1394-1460) of Portugal was the man behind these expeditions, in which priests "served as chaplains to the new trading settlements and as missionaries to neighboring African people." 2 Hence, at the close of the sixteenth century, Christian missionary work had increased significantly south of the Sahara. In Central Africa, and more specifically in the Kingdom of Kongo, the Gospel was preached to the king and his royal family as early as 1484. In 1518, the king's son, Henry (c.1495-c.1526), who trained as a priest in Portugal, was made the first African bishop. ${ }^{3}$ This was followed by the entry

1 William Lane, Jesuits in Zambia: 1880-1991 (Lusaka: Ndola Mission Press, 1991), 1.

2 T.A. [Thomas Allan] Beetham, Christianity and the New Africa (London: Pall Mall Press, 1967), 8.

3 C.P. [Charles Pelham] Groves, The Planting of Christianity in Africa (London: Lutterworth Press, 1958), 128-29. 
of missionaries into Angola in 1560, when Jesuits accompanied Portuguese explorers into the country. Although they did not accomplish much at the time, when they returned in 1574 they were able to convert the king and baptize some of his subjects. ${ }^{4}$

On the southern end of the Sahara, the Portuguese missionaries infiltrated the land from Mozambique and South Africa through the mouth of the Zambezi River into what is now Zimbabwe. In 1561, king, or Mwene Mutapa, of the Shona people and his royal family were baptized by a Jesuit priest, Gonçalo da Silveira $(1526-61){ }^{5}$

Sadly, these Catholic missionary activities at the close of the fifteenth and the dawn of the sixteenth centuries started to diminish by the end of the eighteenth century; when new missionary movements emerged at the beginning of the nineteenth century, there were only a few traces and fading memories of Catholicism in the region. One major reason for this was the diminishing presence of the Portuguese and the subsequent dwindling of their foreign trade policies in this part of the world.

However, at the end of the eighteenth century, a new wave of missionary movements began to emerge, this time initiated by Protestant missionaries. This was partly due to the evangelical revival that had taken place in Europe and North America. According to historian Mark R. Shaw:

At the heart of these evangelical revivals were three powerful convictions. The first was the centrality of the death of Christ for salvation. The second was the necessity of the new birth. The third was a new eschatology that envisioned the spread of Christianity around the world as a prelude to Christ's personal return. ${ }^{6}$

Thus, the end of the eighteenth century and the dawn of the nineteenth saw an increased number of missionary societies south of the Sahara. However, unlike in the pre-eighteenth-century period, this time the evangelization field was split between Protestant and Catholic missionaries.

This chapter explores the missionary movements in Africa at the end of the eighteenth and the beginning of the nineteenth century. During this period, a range of Protestant missionary societies were established that were later sent

4 Ibid., 130.

5 John Baur, 2000 Years of Christianity in Africa, 2nd ed. (Nairobi: Paulines Publications Africa, 2009), 80-81.

6 Mark R. Shaw, The Kingdom of God in Africa: A Short History of African Christianity (Grand Rapids: Baker, 1996), 129. 
to Africa and other parts of the world. By the close of the eighteenth century, both Protestant and Catholic missionaries were working alongside one another to proclaim the kingdom in Africa and elsewhere. The chapter focuses more explicitly on the relationship between the Protestant and Jesuit missionaries who worked in the region that became today's Zambia. This is followed by an analysis of their methods and approaches to evangelization. The chapter concludes with a comparative statistical analysis of the respective achievements and failures of the Jesuits and Protestants in the Zambian mission field.

\section{Historical Background to the Entry of Protestant Missionaries in Zambia}

During the eighteenth-century Protestant evangelical revival in Europe and North America, Protestant churches established missionary societies that would later be sent to Africa to proclaim the Gospel. When Protestant missionaries traveled to the southern part of Africa in the nineteenth century, they found few traces of Catholicism in the region. According to Thomas Allan Beetham, a Methodist minister:

When [...] a new missionary movement to Africa began at the end of the eighteenth century - this time initiated by Protestant Churches and as a result of the evangelical revival in Europe- traces of the previous Catholic movement were almost non-existent. There were a few ruined walls, a crucifix among the sacred objects of a local shrine, and faint memories in tradition of a god who died. ${ }^{7}$

David Livingstone (1813-73) gives similar evidence of the fading traces of Christianity in Angola. He describes two churches and a hospital that lay in ruins as well as the remains of two convents. He further pays tribute to the Jesuits, Benedictines, and Capuchins for their service and missionary work. Speaking of the capital itself, he wrote that "there are various evidences of its former magnificence, especially two cathedrals, one of which, once a Jesuit college, is now converted into a workshop, and in passing the other we saw with sorrow a number of oxen feeding within its stately walls."

7 Beetham, Christianity and New Africa, 8-9.

8 DavidLivingstone,MissionaryTravelsandResearchesinSouthAfrica(London:Ward,Lock\& Co., 1857), 340-41. 
The Protestant missions began in 1792, with the Moravian Church being the first to send its missionaries to Africa. However, despite establishing themselves in the region in 1792, it was only around the 1880 os that these Protestant missionary societies were able to establish missions in Northern Rhodesia, present-day Zambia. Livingstone, representing the London Missionary Society (LMS), was the first Protestant missionary to reach Zambia, making three trips to the country in 1851,1853 , and 1873 . Livingstone's first two trips were to the western province of Zambia. During his third trip, he went as far as Ujiji and Tabora, in present-day Tanzania, before traveling back to central Zambia in Serenje where he died in $1873 .{ }^{9}$ Livingstone's visits to Zambia laid the foundation for the missionary activities that were to take place in later years. In his famous speech at the Senate House of Cambridge University on December 4, 1857 , he made an appeal for volunteers, inviting them to follow in his footsteps. ${ }^{10}$ In response, many Protestant mission stations opened in Africa and, in particular, Zambia.

The first Protestant missionary to set up a mission within the borders of the future Northern Rhodesia was Frederick Stanley Arnot (1858-1914), a Plymouth Brethren missionary, who settled in Barotseland, Lealui, in 1882. When he arrived in South Africa at the age of twenty-four, he had aimed to open a mission along the upper Zambezi River. Once this had been achieved, he hoped to summon reinforcements and to continue the course proclaimed so boldly by Livingstone. As he moved northward into the interior, he began to evangelize among the Toka-Leya and the Tonga people who lived around the Victoria Falls. But before he could do so, he sought to obtain permission from Lewanika (1842-1916, r.1876-1916), the king of the Lozi people. On November 20, 1882, Arnot arrived at Lealui, the capital of Lewanika's kingdom. ${ }^{11}$ Thus, even before Cecil John Rhodes (1853-1902) began to think about the territory beyond the Zambezi River, Arnot had already established himself among the Lozi people of today's Western Province of Zambia.

The LMS was the second missionary group to establish itself among the people of Zambia. Despite being the first missionary society to have influence on the Zambian people through Livingstone, the LMs did not establish a permanent mission until 1883 , ten years after Livingstone's death. Unlike

The Participatory Assessment Group, The Church's Contribution to Development in Zambia (Lusaka: The Group, 2000), 3 .

10 William Monk, ed., Dr. Livingstone's Cambridge Lectures (Cambridge: Deighton Bell, 1860), 24.

11 Peter D. Snelson, Educational Development in Northern Rhodesia 1883-1945 (Ndola: National Educational Company of Zambia, 1974), 27-28. 
most missionary societies, which were denominational, the LMS was generally known for its interdenominational spirit. The first LMS mission stations in Northern Rhodesia were founded at the mouth of the Lofu River, Niamikolo, and Fwambo in 1883, 1885, and 1887 respectively. The mission at Niamikolo was the first mission settlement in the northern part of Zambia.

The third missionary society to establish itself in Northern Rhodesia was the Paris Missionary Society (PMS). Led by François Coillard (1834-1904), the PMS established a mission in the western part of Northern Rhodesia, among the Lozi people. Coillard arrived at the upper Zambezi region in July 1884, accompanied by his wife, his niece, and some Sotho evangelists. Other members of his group included missionaries and people from other denominations and countries. Coillard established his first mission stations at Sesheke, Sefula, Kazungula, and Nalolo in 1885, 1886, 1889, and 1894. In 1887, Coillard opened one of the first schools in the region, which provided training in skills such as plowing and carpentry.

Following the PMS were the Primitive Methodists Missionary Society (PMMS), one of several movements that had broken away from the Wesleyan Methodist Church in the early part of the nineteenth century. The PMMS expedition to Northern Rhodesia consisted of Henry Buckenham (1844-96), his wife, and child; Arthur Baldwin, a young probation minister; and Mr. Frederick Ward, a layman. They left England in April 1889. In March 1890, they left for Kazungula on the Zambezi. The expedition finally arrived at the Zambezi, crossed the river, and settled at Sefula over six months after leaving South Africa. ${ }^{12}$ In 1893 , and having been granted permission by Lewanika, the team settled among the Illa people of the Kafue plains and opened their first mission at Nkala.

While other missionary societies were entering Northern Rhodesia through its southern and western borders, the Presbyterian Missionary Society entered through present-day Malawi, establishing their first mission at Mwenzo, near the Tanzanian border, in 1894. In 1905 and 1907, they established mission stations at Lubwe and Chitambo respectively. In 1965, a year after Zambia became an independent state, the four Protestant Church organizations, namely LMs, PMS, PMMS, and the Presbyterian Church, formed a single church known as the United Church of Zambia (UCz).

In 1905, William Harrison Anderson (1870-1950), a Seventh-day Adventist (SDA), opened a mission station at Rusangu, in Monze, among the Tonga people of the Southern Province. The Anglican missionaries also followed suit, opening mission stations in 1911 and 1912 at Msoro and Mapanza respectively.

12 John P. Ragsdale, Protestant Missions Education in Zambia, 1880-1954 (London: Associated University Presses, 1986), 22-23. 
According to social scientist Drew R. Smith, these mission societies met with different levels of failure in their attempts to establish mission stations, ${ }^{13}$ and it took them some time to succeed in their evangelizing endeavor. Historian Robert I. Rotberg writes of the difficulties that the Protestant missionaries encountered: "Of the approximately 1,500,000 Africans in Northern Rhodesia in 1924, no more than 18,000 had been baptized [...]. No indigenous ministers had been ordained, and none of the missions had tried seriously to encourage the participation of African congregations in the government of the local churches."14 One major reason for this was that the early missionaries were closely associated with the colonial government officials. The PMS, which worked among the Lozi people, for instance, gave the British Southern Africa Company (BSAC) permission to operate in its territories. According to Rotberg:

Missionaries helped the government to collect taxes, several made church membership conditional upon the payment of taxes and nearly all failed to see the contradictory expectation that such action would arouse among Africans [...]. Missionaries were generally content with the Company's method of governance. They frequently said so and defended the Company from overseas criticism. ${ }^{15}$

Because of this, it took time for the Protestant missionaries' work to yield fruit on Zambian soil. However, as time went by, they were able to insert themselves into the local societies and to plant a seed of Christianity in the country. The Protestant churches also contributed toward improving the lives of the local people whom they evangelized, especially through education, health services, and training in agriculture and other skills.

\section{Historical Background to the Entry of Jesuit Missionaries in Zambia}

The first Jesuit missionaries to set foot on the continent of Africa were St. Francis Xavier (1506-52) and his two companions. In 1541, a few months after the founding of the Society of Jesus, Xavier and two other Jesuits spent

13 Drew R. Smith, "Missionaries, Church Movements, and the Shifting Religious Significance of the State in Zambia," Journal of Church and State 41, no. 3 (1999): 525-50, here 528.

14 Robert I. Rotberg, Christian Missionaries and the Creation of Northern Rhodesia: 1880-1924 (Princeton: Princeton University Press, 1965), 139-40.

15 Ibid., 100-1. 
six months in Mozambique while waiting for the wind to take them to Goa. ${ }^{16}$ Despite the long stay, Xavier and his companions did not make contact with the African people and only preached the Gospel to the Portuguese Christians they had traveled with. It was only in the 1560 s that the Jesuits began to plant Christianity in the southern part of Africa, and it would take nineteen further years for another Jesuit to set foot on the southern shores of Africa after Xavier had left for Goa. In 156o, Silveira, a Jesuit priest from a noble Portuguese family, made contact with Mwene Mutapa, the king of the Mashona people of Zimbabwe. In 1561, the then Mwene Mutapa, his mother, and other members of the royal family agreed to be baptized by Silveira. Yet, barely a month after the king's baptism, Silveira was strangled to death, allegedly at the instigation of a local medicine man (ng'anga) and some Muslim traders who had accused Silveira of being a witch and a Portuguese spy. ${ }^{17}$

After Silveira's death, it took some time for Jesuit missionaries to return to this part of the continent; indeed, it was only in 1610 that the next venture into Mozambique took place. On the western side of southern Africa, Jesuits accompanied the Portuguese explorers into Angola in the 1560 s but were unable to accomplish anything until 1574, when they began opening schools, colleges, hospitals, and ministries related to evangelization in both Mozambique and Angola. These missionary activities thrived until the eve of the general suppression of the Society of Jesus in 1773 .

These pre-suppression missionary activities of the sixteenth, seventeenth, and eighteenth centuries did not penetrate into present-day Zambia, and it was only after the lifting of the suppression by Pope Pius VII (1742-1823, r.180o23) in 1814 that Jesuits returned to Africa. During this period, they were able to penetrate the interior of the upper Zambezi, becoming part of a new wave of Catholic evangelization in Africa that began in the nineteenth century. According to Fr. Brendan Carmody:

The Catholic revival of the nineteenth century had begun as a response to the Protestant investment in missions. In 1816, the Roman Propaganda Fide was re-established by Pope Pius VII as the chief authority of missions. Another major contributing factor to the expansion of the Catholic missionary endeavor was the establishment of the Society for the Propagation of Faith by Pauline Jaricot in $1822 .{ }^{18}$

\footnotetext{
16 Bengt Sundkler and Christopher Steed, A History of the Church in Africa (Cambridge: Cambridge University Press, 2000), 70.

17 Elizabeth Isichei, A History of Christianity in Africa from Antiquity to the Present (Lawrenceville, NJ: Africa World Press, 1995), 68.

18 Brendan Carmody, Education in Zambia:Catholic Perspectives (Lusaka:Bookworld, 1999), 4.
} 
The first attempt by the Jesuits to enter present-day Zambia began with the creation of the Zambezi Mission by a decree of the Propaganda Fide. In 1879, the Zambezi Mission, which roughly comprised present-day Zambia and Zimbabwe, was officially opened. Superior General Peter Jan Beckx (1795-1887, in office 1853-87) appointed Henry Depelchin (1822-1900), a Belgian Jesuit, to lead a band of eleven Jesuits across the Limpopo River. By March 1879, these men were ready for the interior journey, and by June 1880 , they had arrived at Pandamatenga, around ninety kilometers southwest of the Victoria Falls. However, they were unable to cross the Zambezi River into the Barotseland of Zambia because of a civil war in that part of the country, and they were also waiting for permission from Lewanika, the Lozi king, to enter the territory. Thus, after establishing a base at Pandamatenga, they decided to cross the Zambezi River farther east. On August 9, 1880, they arrived in the chiefdom of Mweemba of the Tonga people of the Southern Province of Zambia. Mweemba gave them a warm welcome and granted them a piece of land at Siameja village, giving them permission to settle there as long as they wished. Finally, in 1883 , after three years of further waiting, Lewanika granted them permission to enter his kingdom, but he did not give them a permanent place to settle. As a result, the first attempt to establish a Jesuit mission north of the Limpopo ended in failure. According to Thomas McGivern, S.J. (1927-2017) and Sister Mary O'Brien, "Fr. Depelchin was recalled to Europe in 1883 [...]; his mission had failed completely: seven of his men were dead - two by drowning, one by falling from a horse's back, four by fever, and the rest were more or less broken in health and greatly disappointed." 19

It should be noted here that the Jesuits were not the first Catholic missionaries to enter Zambia or to establish a mission. According to historian Hugo F. Hinfelaar:

The people of Zambia had been in contact with Catholic Christendom from the beginning of the eighteenth century onwards. The first contact was with the Portuguese-speaking Dominican missionaries who arrived around 1730 in a market place known as Feira to the Portuguese, situated at the confluence of the Luangwa River and Zambezi River, near the district center of present day Luangwa-Mburuma, the local ruler, had given them a piece of land near the market, Feira, on the northern bank of the river. There one of them had built a chapel and dedicated it to Our Lady of the Rosary. His name was Father Pedro da Santíssima Trinidade (Fr. Peter of Holy Trinity). He was not a Portuguese European, but a

19 Thomas McGivern and Mary O'Brien, Diocese of Monze: A Digest History 1905-2005, ed. Joseph Braun (Monze: Diocese of Monze, 2005), 20. 
Goanese Indian who became a Friar in the order of St. Dominic. He may well have been the first Catholic priest who celebrated the Eucharist in Zambia, though a place of worship appears to have been constructed in Zumbo itself in 1729 by Father Manoel da Conceicao [ sic]. ${ }^{20}$

In the northern part of Zambia, the Missionaries of Africa, popularly known as the White Fathers because of their white robes, entered the region in 1891 and settled near Mambwe-Mwela in the far north, from where they founded a string of mission posts among the Bemba-speaking tribes. ${ }^{21}$ "Their first mission station was established in 1895 in Chief Makasa's area. The mission was opened at Kayambi, 40 kilometers south of Mambwe. Father Joseph Dupont (later nick-named Moto Moto) gained permission to set up a mission."22

Hence the Dominicans had already visited the Luangwa Valley in the 1730s, and the White Fathers had established their mission stations among the Bemba-speaking tribes in the 1890 s.

After the Jesuits' first attempt to set up a mission station north of the Zambezi had failed in 1883, a second, successful attempt was initiated by Peter Prestage, S.J. (1842-1907) and Joseph Moreau, S.J. (1864-1949). In 1902, Prestage and Moreau crossed the Zambezi River and arrived in the chiefdom of Monze. According to Lane, Prestage and Moreau established a cordial relationship with Chief Monze who asked them to open a mission station in the area. But, before they could do so, the two missionaries wanted to perfect their skills in the local language; they consequently identified a potential site for a mission station and, in the meantime, went back to Empandeni outside Bulawayo in Zimbabwe to learn the language. Chief Monze allowed four young men to travel with them.

When these young men arrived in Empandeni with Prestage and Moreau, they were introduced to new skills such as improved plowing methods; they also learned English while Prestage and Moreau learned Tonga. After catechetical instructions, these young men were baptized. In 1905, Prestage, Moreau, and the four young men, this time accompanied by a linguist, Julius Torrend, S.J. (1861-1936), returned to Chief Monze and settled at Chikuni on July 14, 1905. Thus, the Catholic Church was born in the southern part of Zambia. In October 1905, Torrend moved farther north where he established a mission at

20 Hugo F. Hinfelaar, History of the Catholic Church in Zambia (Lusaka: Bookworld, 2004), $1-2$.

21 Ibid., 1.

22 Participatory Assessment Group, Church's Contribution, 5. 
Kasisi. ${ }^{23}$ From 1905 , the Society of Jesus spread rapidly throughout the southern and central parts of Zambia.

\section{Competition between Jesuits and Protestants over Territory and Population}

To a large extent, the encounter and relationship between the early Jesuit and Protestant missionaries was grounded on the policies of the colonial government of the time. Around 1897, the BSAC, led by Cecil Rhodes, had occupied much of the territory north of the Zambezi, which we now call Zambia. In its guidelines for administration, and having experienced how tense the relationship between Christian denominations in Europe and Britain in particular could be, the colonial government's policy was to keep the Catholic and Protestant missionaries apart from each other; no one was to set up a mission station within a ten-mile radius of an already existing mission. ${ }^{24}$

Hence the role of the government was to control and monitor the Jesuit and Protestant missionaries. As such, in their quest to expand and control the region, the colonial government asked some missionary groups to open mission stations in areas they felt they could occupy. For instance, Rhodes, in the context of the area's expansion and development, asked the Jesuits to open a mission north of the Zambezi. Taking into account the boundaries of the Zambezi Mission, laid down twenty years before, and also knowing the mind of Rhodes, while being conscious of their mission to spread the Gospel, the Jesuits agreed to open mission stations within the boundaries of the Zambezi Mission. ${ }^{25}$ Around the same time, other missionary groups were also emerging with the aim of evangelizing Africans. As these different missionary societies went about realizing this aim, they encountered each other in the field of evangelization, and in some contexts these encounters were characterized by competition over territory and population. In the western part of Zambia, for instance, when Jesuits first arrived in the territory, they were refused entry into the Barotseland by King Lewanika until three years later. And when they were eventually given permission to enter, the king refused to give them a permanent place to settle. It would appear that the Protestant missionaries who had settled there had poisoned the mind of the king, urging him not to

23 Lane, Jesuits in Zambia, 9.

24 Edward P. Murphy, interview with Choobe Maambo, Jesuit novitiate, June 27, 2016.

25 Lane, Jesuits in Zambia, 8. 
give land to the Jesuits for fear of competition. ${ }^{26}$ According to historian Edward Murphy, "the result was that if permission was granted to one body to settle in a territory, these would advise the chief to keep out all other Christian organizations."27

The Protestant and Catholic missionaries sometimes accused one another of trespassing into each other's territories. Historian Edward H. Berman claims that "Catholics were unwilling to abandon even part of the African field to the Protestant societies. To do so would be tantamount to denying the worldwide mission of the Catholic Church and admitting the legitimacy of the sixteenthcentury schism between Rome and Wittenberg." ${ }^{28}$ Generally, the colonial government's policy of monitoring and controlling the missionaries in their territories seems to have been ineffective. As Berman asserts, "the inability of [the] colonial government to limit missionary expansion in their territories led to great overlapping, and not infrequently to conflict, between rival denominations attempting to gain an advantage over a competing society." 29

\section{The Rivalry between Jesuit and Protestant Missionaries}

Berman describes the relationship between Jesuits and Protestants as being "very bitter," ${ }^{30}$ with the rivalry that characterized the sixteenth-century Reformation in Europe manifesting itself in the relationship between the missionaries as they engaged in evangelization activities within Zambia. The general attitude of the Jesuits was that Protestants were heretics who were destined for eternal damnation. Similarly, Protestants saw Jesuits to be in serious error and in danger of eternal damnation.

One example that illustrates this rivalry concerns the Protestant missionary societies' attempts to harmonize missionary activities. Between 1914 and 1945, Protestant missionary societies formed a body known as the General Missionary Conference (GMC), which called for a series of meetings to foster cooperation and coordination and to find ways of harmonizing their

26 Ibid., 7 .

27 Edward P. Murphy, "First Zambesi Mission," in A History of the Jesuits in Zambia: A Mission Becomes a Province, ed. Edward P. Murphy (Nairobi: Paulines Publications Africa, 2003), 6o-86, here 61 .

28 Edward H. Berman, ed., African Reactions to Missionary Education (New York: Teachers College Press, 1975), 21.

29 Ibid., 20-21.

$30 \quad$ Ibid., 21. 
missionary activities in the region. The main aim of the GMC as elaborated by historian Peter Bolink was "to promote cooperation and brotherly feeling between different missionary societies: to labor for the most speedy and effective evangelization of the races inhabiting North-western Rhodesia; to enlighten public opinion on Christian missions; [and] to watch over the interests of the Native races." 31

The Jesuits did not take part in the conference until its third meeting in 1922, which was held at Kafue. One of the policies advanced at this meeting was the comity agreement, which limited the overlapping of missionary societies into other missionaries' spheres of influence. Rev. Douglas S. Gray (1883-1963), who spoke on this topic, "pleaded that the general principle of respecting the areas already occupied be respected." ${ }^{32}$ In order to enhance respect, coexistence, and cooperation between the different missionary societies, the GMC proposed that each society should stick to its boundaries and spheres of influence. The agreement stipulated that:

1. This conference while recognizing that spheres of influence may only be temporary, yet holds strongly that at this early stage in the development of mission work, there is ample room for missions to occupy distinct areas, and it would therefore remind all the missionary societies of the waste and friction that result from overlapping and urge them to avoid this evil wherever possible.

2. This conference trusts that any mission wishing to open works in a new area will first communicate with the executive of the conference.

3. In the event of a new society wishing to open work in the territory, or a society already at work in the territory wishing to open a new sphere, the conference would esteem it a favor if the administration would refer such society to its executive for information as to vacant areas before granting permission. ${ }^{33}$

The colonial government supported this policy and worked hard to implement it. "As early as 1899 , the administrator recognized the need to take some action to control the operations of the missionary societies. Spheres of influence

31 Peter Bolink, Towards Church Union in Zambia: A Study of Missionary Co-operation and Church Union Efforts in Central Africa (Franeker: T. Wever, 1967), 132.

32 Proceedings of the General Missionary Conference of Northern Rhodesia, 1922 (Livingstonia: Mission Press, 1923), 13.

33 Ibid. 
had been demarcated for each society working in Northern Rhodesia." ${ }^{34}$ Yet the policy ultimately failed, with the Jesuits being among the first missionary groups to disregard the agreement. According to Bolink:

It was to be expected that Roman Catholic Missions would no longer accept such a restricting agreement [...]; other prominent cases, in which missions refused to comply with the government's sphere of influence policy were to occur in the Southern and Central provinces where, in particular, Jesuit missionaries objected to that policy. ${ }^{35}$

Thus, because of this restrictive policy, in 1935 the Jesuits stopped participating in the GMC upon instruction from Rome. Part of the reason for the Jesuit withdrawal was that they intended to expand their missions, and they did not want to be restricted by the policy of the sphere of influence that the conference was trying to uphold. ${ }^{36}$ In the period after their withdrawal,

the Roman Catholic missions greatly extended their influence mostly in Protestant areas, by building stations, usually within a distance of five to fifteen miles from existing Protestant missions. This caused much bitter feeling and strife, creating a deplorable picture of Christian disunity before the eyes of the people who had to be won for Christ. ${ }^{37}$

Hence the relationship between Jesuits and Protestants was sometimes characterized by rivalry and bitterness. According to Carmody, "the rather exclusive mission of the Catholic Church of that time meant that even Protestants were regarded as being in the shadow of death. Because of this general Catholic attitude to Protestants at this time, Catholics did not wish to be an integral part of these conferences." ${ }^{38}$ Rotberg summarizes this rivalry as follows:

The missionaries to Northern Rhodesia came from diverse backgrounds and brought to Africans the experience of a variety of occupations. They were fiercely independent men and they fought bitterly with one another [...] usually to the detriment of their evangelical objectives. In their individual journals and correspondence, expressions of fractiousness,

\footnotetext{
34 Ragsdale, Protestant Missions Education, 44.

35 Bolink, Towards Church Union, 128, 129.

$36 \quad$ Ibid., 131.

37 Ibid.

38 Carmody, Education in Zambia, 7.
} 
spitefulness, and jealousy compete with one another for space in numerous letters supposedly written more in sorrow than in anger. Indeed, missionaries seemed to spend as much time and energy committing these quarrels to paper as they did in seeking to accomplish conversion. ${ }^{39}$

A good example of these tensions is the encounter between Moreau and Anderson. When Moreau arrived in the Monze area in 1902, he identified a place where he could set up a mission. As already mentioned, after identifying a site he returned to Empandeni, Zimbabwe, to study the Tonga language. In 1905 , he returned to the site to begin his missionary work. However, upon arriving, he found that Anderson, the SDA missionary, had settled there two days earlier. This did not go down well with Moreau; he and his camp moved farther south in search for a new place, and the relations between the two men would remain strained for some time. ${ }^{40}$

In the western part of Zambia, the Jesuits encountered similar conflicts with the Dutch Reformed Church and the Methodists. "On the western side, the Dutch Reformed Church was also forced to compete with the expansive design of the Jesuits," says Rotberg. ${ }^{41}$ Talking about the encounter with the Methodists and the Adventists, one of the leading Jesuits claimed that

the day may not be far when the country will be overrun by Methodists and other sects [...]. There is still hope for us to make the Tonga nation a Catholic nation. [Moreover], I am now building our seventh outstation. It is a victory over the Adventists who had tried hard to get it. ${ }^{42}$

The Methodists responded to the Jesuit threat by opening a number of schools in Jesuit spheres of influence. In his diary, Oliver Roebuck, a Methodist missionary, states:

We hear that the Jesuits are keen to start work in two places where we have existing work [...]. Their Father Superior in these climes is a Pole, or some such nationality [...]. Here we are in this district, doing the best we can. The Jesuits want to come in the same place, whilst to the North there is a huge area untouched $\left[\ldots . .{ }^{43}\right.$

39 Rotberg, Christian Missionaries, 156.

40 Snelson, Educational Development in Northern Rhodesia, 95.

41 Rotberg, Christian Missionaries, 87.

42 Ibid.

43 Ibid., 88. 


\title{
Jesuit and Protestant Methods and Approaches to Evangelization
}

Despite the tension and competition between Jesuits and Protestants, the missionary societies used similar methods as part of their evangelization work. In the initial stages of evangelization, both set up centers of Christian influence. In Protestant terms, these centers were called mission stations. According to Beetham:

\begin{abstract}
Whereas in West Africa the center of Christian influence was the "mission house," in southern Africa, it was more often the mission station. Several missionary families lived there together. There were huts for the mission employees who looked after the wagon-teams and worked on the farm. Maize and vegetables were grown for the whole community including the small primary boarding school or training institution. ${ }^{44}$
\end{abstract}

These missions served as centers of learning and catechetical instructions, and by 1924 numerous stations had opened throughout Zambia. From these missions, Protestants were able to reach out to the local population.

In Catholic terms, the centers of Christian influence were called Christian villages. From the early days of their establishment, Jesuits attempted to set up such villages. In the Chikuni mission, for instance, Moreau acquired tracts of land, established villages, and invited families to set up homes. ${ }^{45}$ By 1924, the Chikuni mission alone had about four Christian villages that the priest frequently visited. Those who lived within these villages were expected to lead monogamous lives, attend Mass, and follow catechetical instructions. ${ }^{46}$

44 Beetham, Christianity and the New Africa, 13.

45 Lane, Jesuits in Zambia, 11.

46 However, the Christian village approach was questioned by some since it required having a good number of priests to cover the ground. One unidentified speaker at the 1920 Jesuit conference held at St. George's in Bulawayo, Zimbabwe, had this to say about the Christian village: "To have Christian kraal is, of course, the ideal thing: but the time for this has not come yet; for the existence of Christian kraal means too much centralization, whereas our great need is to widen our spheres of influence, and we have, as it is, far too few missionaries for this." See "Minutes of Missionary Conference Held at St. George's in Bulawayo," June 22-27, 1920, as quoted in Carmody, Education in Zambia, 8-9. Despite this view, Christian villages continued to be the basic spheres of influence. Thus, "conversion was often achieved through a village or school system that included repetition, memorization, of catechetical formulae, and at least outward conformity to certain demands like monogamy, Sunday Mass, and frequent confession." Brendan Carmody, "Conversion 
One element given greater emphasis in the Catholic evangelization was the importance of making material improvements to people's lives as a way to attract them to the faith. At that time, there were persistent famines and people needed food, clothing, and money to pay the taxes that had been introduced by the colonial government. In the desire to improve people's lives, Moreau set himself the task of improving their farming methods by introducing the plow. In the process, he attracted a large number of people to the faith.

Jesuit Christian villages and Protestant mission stations were later superseded by the school system, ${ }^{47}$ which became a means to influence the local population. This is one of the reasons why Jesuits established schools wherever they opened a mission. "When a school had been set up, one could begin to claim a rather exclusive right to the population of the area under what became known as the spheres of influence," says Carmody. ${ }^{48}$ For the Jesuits, any program of study was school oriented. What was probably typical of the Jesuits was that, in their missions, they established schools that became training centers for catechists. However, schools were not exclusive to the Jesuits. In fact, one could claim that wherever the early missionaries set up a mission or a church, there too one found a school. Among the early mission stations that were established by LMS, PMS, Presbyterian, Anglicans, and the SDA, there were schools. According to the Participatory Assessment Group's research, among the first missions in Zambia that were founded at Niamikolo, Fwambo, Kambole, Kawimbe, and Chikuni, schools were set up as well. In 1912, the Methodist Missionaries founded the Chipempi mission where they started a school for girls. Both the Anglicans and SDAs opened mission stations and centers of early learning in the Southern Province of Zambia. The Dutch Reformed Church opened a station at Magwero where they started a school for the blind, deaf, and dumb, as well as physically and mentally challenged children. All these stations and schools, both Jesuit and Protestant, were meant to be vehicles of evangelization.

\section{Differences in Jesuit and Protestant Theological Approaches in Zambia}

One major difference between the Jesuits and the Protestants in their approach to evangelization was in the area of theology. The missionaries came to Africa from different theological backgrounds. The Protestant theology at

to Catholicism in Zambia: 1891-1924," Missiology: An International Review 27, no. 2 (1999): 195-209, here 195 .

Ibid.

48 Ibid., 9 . 
the time was more influenced by Reformation theology, while Jesuit theology reflected pre-Vatican II (1962-65) principles. The Protestants rejected most of the Catholic Church's doctrinal teaching. At the heart of Protestant theology was sola scriptura (the supremacy of scripture in matters of faith, life, and conduct); sola fide (justification by grace alone through faith); and the priesthood of all believers, meaning that all believers are priests before God through Jesus the high priest. As a result, Protestant theology rejected papal supremacy, the merit of good works for salvation, veneration of Mary and the saints, and all but two sacraments instituted by Jesus: baptism and Holy Communion. The doctrines of transubstantiation, purgatory, and the requirement to confess to a priest were rejected.

Jesuits and Catholics in general held to the principle that extra ecclesiam nulla salus (outside the church there is no salvation). Therefore, Jesuits viewed the Protestant missionaries as heretics under the shadow of death and destined for eternal damnation. For Jesuits and indeed for the entire Catholic Church of that time, being baptized into the Catholic Church was the only way to taste eternal salvation. Baptism into and membership of the Catholic Church was absolutely necessary for salvation. Without these two elements, one was condemned to eternal death. But the Protestant missionaries did not believe that baptism and membership into the Catholic Church were necessary for eternal salvation.

The other area of theology that divided Jesuits and Protestants was polygamy. In most Zambian communities, polygamy was accepted and divorce permitted on occasion, both of which were forbidden by the Roman Catholic Church. As such, for the Jesuits, the official attitude toward polygamy remained rather conservative, in line with the thinking of the universal Catholic teaching. This is why when someone who lived within the Christian village turned to polygamy, he or she was asked to leave the village. For the Jesuits, strict adherence to the practice of monogamy was sometimes perceived to be a sign that Catholics, as opposed to Protestants, were selective in terms of the people they attracted. One chief had this to say about Catholic missionaries:

Your religion is a true religion. The Protestants recruit all the undesirable characters and make them more insolent and thievish. One of our men was sent away from our village because of polygamy. He went to Kawimbe and after a few months he was baptized together with his wives. They accept anyone and they pick up all the weeds we throw over the hedge. ${ }^{49}$

49 Mponda-Mambwe, missionary diary 1891-95 (copy held at the Missionaries of Africa Archives in Lusaka, Zambia, and original diary said to be held at the White Father's Archives in Rome). 
Despite the conservative approach in the preservation of their Catholic tradition, Jesuits were perceived to be less negative than Protestants toward African customs, rites, and cultures. ${ }^{50}$ Moreau, for instance, participated fully in local customs and rites. He went to the shrine with people to pray for rain and attended funerals and initiation ceremonies that were carried out according to local customs. At one point, he even stated that he wished polygamous people could become practicing Catholics. In a letter to his superior, dated August 27, 1932, he had this to say:

Last Thursday there was a great gathering at Monze's grave [burial ceremony of the local chief], at least 1500 people. I went there myself and I preached to the crowd from a heap of stones. I told them that I thought my place was also to be with them, their joys as well as their sorrow. ${ }^{51}$

\section{A Comparative Statistical Analysis of the Success of Jesuit and Protestant Missionaries in Zambia}

The following analysis aims to assess the successes and failures of the Jesuit and Protestant missionaries. It indicates, at least tentatively, that Jesuit missionaries had greater success than Protestant missionary societies in spreading the message of Christ. This is evident in the numbers converted, as well as the number of institutions they established, such as schools, parishes, hospitals, agricultural centers, social justice institutions, youth training centers, cultural institutions, and human rights and social apostolates, among other things. Thus, while Protestant missionaries were the first to establish mission stations in Zambia, Catholic missionaries, especially the Jesuits who established their missions at a later date, appear to have superseded Protestant influence by the mid-twentieth century. Early Jesuit missionaries were highly involved in a variety of apostolates, which demonstrates how far and wide they went to attract the local population. At the beginning of the twentieth century, in the Southern Province alone, there were no fewer than eight Protestant missionary groups, yet the Jesuits were able to cover more ground and population than these varied groups.

\footnotetext{
5o Hastings, Church in Africa, 197.

$5^{1}$ Moreau to superior, letter dated July 19, 1932 (copy held at the Jesuit Archives in Lusaka, Zambia, Box A1).
} 
Covering much ground does not, of course, necessarily entail success. However, in the case of the Jesuit missionaries, they did not just cover considerable ground; they also attracted a large number of converts. According to the 1924 GMC of Northern Rhodesia held in Kafue between June 9 and 15, there were about eighteen thousand baptized Zambians from fourteen Protestant missions, while there were forty-five thousand baptized Zambians who belonged to the Catholic Church. ${ }^{52}$ The dominance of Catholicism has continued up to more recent times. In a survey by the Evangelical Fellowship of Zambia in 1994, Lusaka, the capital city, registered the following results:

Catholic attendance on a Sunday was 102,065 (10.39\% of Lusaka's total population). Attendance at churches belonging to Evangelical Fellowship of Zambia was $37,563(3.61 \%)$; at Christian Council churches 16,582 (1.66\%); for the SDA 12,183 (1.24\%); for New Apostolic Church 25,882 $(2.63 \%)$, and at Independent Churches a mere 5,939 (0.58\%). There is another category of Sunday Churches which originate from or are related to overseas churches, with attendance of 12,192 (1.24); presumably, this consists mainly of Jehovah's Witnesses. Thus Catholics are by far the most dominant. ${ }^{53}$

By 1924, there were about seven thousand Catholics within the Jesuit missions, and eighty-three schools with 4,300 registered children. ${ }^{54}$ By 1964, Jesuits managed 168 primary schools. And while primary schools run by different church organizations were all given to the government upon the country's independence, "in mid-1994, there were still forty-one church secondary schools, twenty-seven run by Catholics, five by UCZ, four by the Brethren in Christ, two by the Anglican Council, and one each by the sDAs, the Evangelical Church in Zambia, and other autonomous church body."55

The Jesuits created almost all of the parishes in Southern, Central, and Lusaka Provinces and many more in other parts of the country before handing them over to the local leadership and to other Catholic religious congregations. Similarly, the number of baptized Christians in areas managed by Jesuits was and is still much higher compared with all Protestant groups. Today, the

52 Proceedings of the General Missionary Conference of Northern Rhodesia, Kafue: gth June to 15th (Cape Province: Lovedale Institution Press, 1925), 86.

53 Paul Gifford, African Christianity: Its Public Role (London: Hurst, 1998), 187.

54 Snelson, Educational Development in Northern Rhodesia, 89.

55 Gifford, African Christianity, 189. 
Catholic Church in Zambia is the largest Christian denomination, with about thirty percent of the population.

There are several reasons for the greater degree of success of the Jesuit missionaries in comparison with the Protestant missionaries. First, when Protestants arrived in the area, they encountered a number of obstacles and made a number of mistakes. When the Jesuits arrived, they were able to capitalize on these mistakes by learning from the failures of the Protestants. In his discussion of the factors behind the Catholic missionaries' success, Beetham points out that Catholics began their mission when medicines for tropical diseases were being discovered. As such, there were fewer deaths this time around, and they were also able to attract new recruits from Europe. The re-introduction of Propaganda Fide as a central body coordinating and supporting Catholic missionary efforts was also highly significant: "In contrast to the larger Protestant societies, the responsibility of many of the Catholic orders was limited to Africa and [specifically], to particular regions in Africa. This made possible a greater concentration of resources," says Beetham. ${ }^{56}$

\section{Conclusion}

While the focus of this chapter has been on the different approaches to evangelization as employed by Jesuits and Protestants in Zambia, and the competition and rivalry between them, it is worth concluding on a more positive note by pointing out that there was a great amount of cooperation, coordination, and collaboration as well, with some cordial and mutual relationships between individual missionaries from across the denominational boundaries. As was mentioned, in the initial stages of the GMC, Jesuits declined to participate and thus conflicts between them and the Protestants could not be resolved easily. But in the later stages, the Jesuits opted to be part of the conference, giving rare evidence of institutional, not simply individual, collaboration. This move led to some dialogue among the different groups, which reduced the level of competition and rivalry.

Another example of Jesuit-Protestant collaboration was that which took place between Torrend, a Jesuit, and John R. Fell (1879-1947) of the Kafue Institute, in proofreading a translation of the Bible into the Chitonga language in April $1927 .{ }^{57}$ In another example, when Moreau, the Jesuit, was stranded with his goods at a rail station, it was Anderson, the SDA missionary, who

$5^{6} \quad$ Beetham, Christianity and New Africa, 15-16.

57 Ibid., 45 . 
bailed him out, and when Moreau fell from the back of a horse, it was again Anderson who treated and cared for him. These examples stress the fact that inasmuch as strife existed between Jesuits and Protestants in Zambia, these missionaries also helped each other in moments of need.

\section{Bibliography}

Baur, John. 2000 Years of Christianity in Africa. 2nd ed. Nairobi: Paulines Publications Africa, 2009.

Beetham, T.A. [Thomas Allan]. Christianity and the New Africa. London: Pall Mall Press, 1967.

Bentley, Holman W. Pioneering on the Congo. 2 vols. New York: Fleming H. Revell, 1900.

Berman, Edward H., ed. African Reactions to Missionary Education. New York: Teachers College Press, 1975.

Bolink, Peter. Towards Church Union in Zambia: A Study of Missionary Co-operation and Church Union Efforts in Central-Africa. Franeker: T. Wever, 1967.

Carmody, Brendan. "Conversion to Catholicism in Zambia: 1891-1924." Missiology: An International Review 27, no. 2 (1999): 195-209.

Carmody, Brendan. Education in Zambia: Catholic Perspectives. Lusaka: Bookworld, 1999 .

Collins, Bernard. Lusinizyo. Lusaka: Commercial Press, 1958.

Gifford, Paul. African Christianity: Its Public Role. London: Hurst, 1998.

Groves, C.P. [Charles Pelham]. The Planting of Christianity in Africa. London: Lutterworth Press, 1958.

Hastings, Adrian. The Church in Africa: 1450-1950. Oxford: Clarendon Press, 1994.

Hinfelaar, Hugo F. History of the Catholic Church in Zambia. Lusaka: Bookworld, 2004.

Isichei, Elizabeth. A History of Christianity in Africa from Antiquity to the Present. Lawrenceville, NJ: Africa World Press, 1995.

Lane, William. Jesuits in Zambia: 1880-1991. Lusaka: Ndola Mission Press, 1991.

Livingstone, David. Missionary Travels and Researches in South Africa. London: Ward, Lock \& Co., 1857.

McGivern, Thomas, and Mary O'Brien. Diocese of Monze: A Digest History 1905-2005. Edited by Joseph Braun. Monze: Diocese of Monze, 2005.

Monk, William, ed. Dr. Livingstone's Cambridge Lectures. Cambridge: Deighton Bell, 1860.

Murphy, Edward P., ed. A History of the Jesuits in Zambia: A Mission Becomes a Province. Nairobi: Paulines Publications Africa, 2003.

Participatory Assessment Group. The Church's Contribution to Development in Zambia. Lusaka: The Group, 2000. 
Proceedings of the General Missionary Conference of Northern Rhodesia, 1922. Livingstonia: Mission Press, 1923.

Proceedings of the General Missionary Conference of Northern Rhodesia, Kafue: gth June to 15 th. Cape Province: Lovedale Institution Press, 1925.

Ragsdale, John P. Protestant Missions Education in Zambia, 1880-1954. London and Toronto: Associated University Presses, 1986.

Rotberg, Robert I. Christian Missionaries and the Creation of Northern Rhodesia: 18801924. Princeton: Princeton University Press, 1965.

Shaw, Mark R. The Kingdom of God in Africa: A Short History of African Christianity. Grand Rapids: Baker, 1996.

Smith, Drew R. "Missionaries, Church Movements, and the Shifting Religious Significance of the State in Zambia." Journal of Church and State 41, no. 3 (1999): 525-50.

Snelson, Peter D. Educational Development in Northern Rhodesia 1883-1945. Ndola: National Educational Company of Zambia, 1974.

Sundkler, Bengt, and Christopher Steed. A History of the Church in Africa. Cambridge: Cambridge University Press, 2000.

Westermann, Diedrich. Africa and Christianity. Oxford: Oxford University Press, 1937. 